Karolina Sindrewicz

DOI: 10.33896/PorJ.2019.9.5

(Uniwersytet Warszawski,

e-mail: sindrewicz.karolina@gmail.com)

\title{
STRUKTURY ZDANIOWE Z CZASOWNIKAMI RUCHU W MOWIE DZIECI DWU- I TRZYLETNICH
}

Zadanie, jakie przed soba postawiłam, to zwrócenie uwagi na akwizycję podsystemów składniowego i fleksyjnego w rozwoju mowy. Interesuje mnie przede wszystkim ocena kompetencji składniowej dzieci w procesie akwizycji języka, w szczególności zaś stopień rozwoju struktur zdaniowych prostych. Przedstawiona w artykule analiza wypowiedzeń konstytuowanych przez czasowniki ruchu stanowi jedynie wstęp do dalszych badań nad akwizycja wymienionych podsystemów u dzieci w wieku przedszkolnym.

Zgromadzony materiał językowy obejmuje fragmenty wypowiedzi zebranych podczas badań prowadzonych w trzech żłobkach na terenie gminy Praga Północ. Objęto nimi 50 dzieci. Podstawę analizy stanowią wypowiedzi powstałe podczas swobodnych rozmów, odpowiedzi na pytania zadawane przez osoby prowadzace badanie oraz fragmenty wypowiedzi dotyczących opisów obrazków. Użycie do badania materiałów obrazkowych wpłynęło na ograniczenie zakresu treściowego wypowiedzi, co umożliwiło ich porównywanie.

\section{CZASOWNIKI RUCHU - CHARAKTERYSTYKA SEMANTYCZNO-SKEADNIOWA}

Polskie czasowniki ruchu były przedmiotem zainteresowania wielu językoznawców. Spośród polskich publikacji należy wymienić przede wszystkim teksty Macieja Grochowskiego [1973; 1974], Bożenny Bojar [1977; 1979], Barbary Kudry [1993], Zofii Kubiszyn-Mędrali [2006-2007], Pauliny Witkowskiej [2017].

Czasowniki ruchu, nazywane także czasownikami motorycznymi lub przemieszczania się, charakteryzowane sa jako klasa mająca wspólny element znaczenia, choć jednocześnie wewnętrznie zróżnicowana. Zazwyczaj wyodrębniane sa na podstawie kryterium semantycznego (ze względu na pojęcie ruchu). Definiowane sa jako oznaczające postrzegalną wzrokowo zmianę położenia przedmiotu (lub jego części), lokalizowanego 
w przestrzeni względem jakiegoś układu odniesienia [Grochowski 1974, 100; Bojar 1979, 28], a dzielone sa najczęściej na dwie podklasy, ze względu na kierunek ruchu. Wyróżnia się więc czasowniki ruchu jednokierunkowego (np. iść, biec, lecieć, jechać, płynać, pełzać) oraz wielokierunkowego (np. chodzić, biegać, latać, jeździć, pływać, pełzać), przy czym te drugie - jak zauważa Jurij Apresjan [2000, 80] - często traktowane sa jako semantycznie pochodne od pierwszych. J. Apresjan, zwracając uwagę na semantyczne zróżnicowanie omawianej klasy predykatów, zauważa także, że czasowniki ruchu wielokierunkowego są semantycznie związane $z$ czasownikami ruchu wahadłowego (kołysać się, huśtać się, drgać, kiwać się), oznaczającymi czynność składająca się $z$ wyraźnie wydzielonych kwantów ruchu. ${ }^{1}$ Odrębna grupę stanowia motoryczne czasowniki kauzatywne, np. nieść, wieźć, huśtać, bujać. Możliwe sa rzecz jasna dalsze uszczegółowienia charakterystyk semantycznych. Czasowniki przemieszczania się można np. klasyfikować ze względu na kierunek ruchu: w górę (wchodzić, wbiegać) i w dół (schodzić, zbiegać). Dodatkowo warto stwierdzić, że istnieje liczna grupa derywatów przedrostkowych pochodnych od bezprzedrostkowych czasowników ruchu jednokierunkowego (np. wejść - wbiec - wjechać, wyjść - wybiec-wyjechać) [Apresjan 2000, 80-81].

Za podstawę prowadzonych $\mathrm{w}$ tym artykule analiz przyjmuję propozycję klasyfikacyjna Zofii Zaron [2012], która wskazuje kategorie semantyczno-składniowe pozwalające wyodrębnić i opisać interesująca mnie grupę czasowników. $Z$. Zaron uznaje, że struktury zdaniowe wyznaczane przez wspomniana klasę predykatów otwieraja od 4 do 7 pozycji składniowych. ${ }^{2}$ Należą do nich: wykonawca czynności (agens), obiekt, narzędzie, lokalizatory: punkt wyjścia (skąd) - punkt docelowy (dokad) i trasa (którędy) oraz cel. O specyfice grupy stanowia w tym ujęciu trzy pozycje lokatywne. To one odróżniaja orzeczenia motoryczne od wszelkich innych. Jako pozycje implikowane na poziomie semantycznym w strukturach powierzchniowych moga być rozmaicie realizowane (wybór tych, które będą zrealizowane zależy przede wszystkim od tematu wypowiedzi [por. Zaron 2012, 78]). Pozostałe pozycje zostały wykorzystane do wewnętrznej dyferencjacji grupy. W zależności od tego, czy implikowana jest pozycja narzędzia sensu stricto (obiekt materialny) czy pseudona-

$1 \mathrm{~W}$ ruchu wielokierunkowym kwantem jest przemieszczenie $z$ jednego punktu do drugiego, w którym kierunek jakoś się zmienia. Z kolei w ruchu wahadłowym jest to ruch od jednego punktu skrajnego do drugiego, w którym kierunek zmienia się na przeciwny [Apresjan 2000, 80].

2 Warto przypomnieć, że część badaczy o zbliżonej orientacji metodologicznej ogranicza liczbę pozycji do jednej [Grochowski 1974] lub dwóch [Karolak 2002]. W artykule nie podejmuję się opisu ujęć odmiennych, co wymagałoby osobnego, obszernego opracowania Odnotuję tylko, że rozbieżności przynajmniej po części sa pochodna przyjętego w każdym $z$ opisów aparatu pojęciowego, w szczególności zaś podziału na pozycje obligatoryjne i fakultatywne. 
rzędzia (część ciała) predykaty motoryczne dzielą się na dwie podklasy: czasowniki ruchu prostego (autonomicznego) otwieraja miejsce dla nazw części ciała, a czasowniki motoryczne złożone - dla nazw przedmiotów materialnych. Cecha charakterystyczna całej grupy jest to, że pozycja podmiotu jest otwierana dla agensa, który jest zarazem obiektem działania: przemieszczając się, zmienia w przestrzeni (i czasie) położenie swojego ciała, tzn. obiektu, wykorzystując w tym celu (a) pseudonarzędzie, (b) narzędzia sensu stricto - obiekty fizycznie proste lub złożone. Jeśli oprócz takiego agensa-obiektu implikowana jest osobna pozycja obiektowa („co-obiekt”), mamy do czynienia $z$ czasownikami kauzatywnymi [Zaron 2012, 75-78].

Przyjmuję, że omawiana grupa czasowników wymaga pozycji wskazującej na celowość działań agensa. Jest to pozycja, która budzi wiele kontrowersji. J. Apresjan uważa ją za fakultatywną dla większości czasowników ruchu ukierunkowanego, w szczególności dla wszystkich czasowników ruchu jednokierunkowego. Uczony podkreśla jednak, że

takie walencje, które maja wysoki stopień prawdopodobieństwa (...) powinny być uwzględniane przy ustalaniu struktury walencyjnej wyrazu [Apresjan 2000, 125].

Z. Zaron postuluje obligatoryjność pozycji celu, wskazującej na intencjonalność działań agensa dla orzeczeń motorycznych złożonych i kauzatywnych. ${ }^{3}$ Orzeczenia motoryczne proste nie przesadzaja jej zdaniem celowości działania [Zaron 2012, 78]. Skłaniam się ku tezie, iż dla wszystkich orzeczeń motorycznych pozycja celu jest obligatoryjna, choć $z$ pewnościa potrzeba badań, które pozwoliłyby ją potwierdzić.

Uwzględniając powyższe ustalenia, podstawowe struktury zdaniowe wyznaczane przez wymienione podklasy czasowników ruchu przedstawić można następująco: ${ }^{4}$

- Orzeczenia ruchu prostego (motoryczne proste):

ktoś [agens] - przemieszcza się - skądś - dokądś - którędy [lokalizatory] - za pomoca czegoś [pseudonarzędzie] - w jakimś celu [cel], np. Jan poszedł $z$ domu do sklepu przez las.

3 Trudno rozstrzygnąć, czy wyrażenia typu: do pracy, do lekarza, do sklepu realizują pozycję lokalizatora adlatywnego - punktu końcowego, czy celu. Przyjmuję, że w tego typu wypadkach jedna forma realizuje dwie funkcje składniowe.

${ }_{4}$ Jest to modyfikacja propozycji $Z$. Zaron przedstawionej w publikacji $W y$ brane problemy składni funkcjonalnej [2012]. Jak wspomniałam, uczona pozycje celu wprowadza do wzorców konotacyjnych czasowników motorycznych złożonych i kauzatywnych [Zaron 2012, 78]. W przyjętej przeze mnie roboczej propozycji jest ona obligatoryjna dla wszystkich grup czasowników ruchu. Przyjmuję także, że orzeczenia kauzatywne nie powinny być klasyfikowane jedynie jako podklasa orzeczeń motorycznych złożonych, por. iść-nieść. 
- Orzeczenia motoryczne złożone:

ktoś [agens] - jedzie - skąśs - dokadś - którędy [lokalizatory] - za pomoca czegoś [narzędzie] - w jakimś celu [cel], np. Ania jedzie pociagiem $z$ Warszawy do Gdańska przez Bydgoszcz na koncert.

- Orzeczenia motoryczne kauzatywne:

ktoś [agens] - wiezie - kogoś/coś [obiekt] - skąśs - dokadś - którędy [lokalizatory] - za pomoca czegoś [narzędzie] - w jakimś celu [cel], np. Jan wiezie Anię samochodem autostrada $z$ Warszawy do Gdańska przez Bydgoszcz na koncert.

Jak wspomniałam wcześniej, klasa czasowników ruchu jest niejednolita. Na poziomie semantycznym różnicuje je typ narzędzia, typ obiektu - co widać w zaprezentowanej klasyfikacji, a także kierunek i czas trwania ruchu. Ze względu na kierunek Z. Zaron, podobnie jak J. Apresjan, wyróżnia orzeczenia ruchu jednokierunkowego i wielokierunkowego, te ostatnie dzieli $z$ kolei na orzeczenia ruchu niewahadłowego i wahadłowego.

\section{CZASOWNIKI RUCHU W MOWIE DZIECI}

Wybór czasowników oznaczających przemieszczanie się jako obiektu obserwacji nie jest przypadkowy. Analizując materiał językowy zebrany podczas badań przesiewowych, przeprowadzonych w odniesieniu do grupy ponad 160 dwu- i trzylatków, zauważyłam, że predykaty te należą do czasowników, których realizacja przez dzieci charakteryzowała się regularnością i dużą poprawnością użycia. ${ }^{5}$

Moje pierwsze spostrzeżenia dotyczące frekwencji czasowników ruchu $\mathrm{w}$ wypowiedziach dzieci znalazły potwierdzenie w literaturze. Kilkanaście czasowników ruchu znajduje się w Inwentarzach Rozwoju Mowy i Komunikacji: Słowa i Gesty (dalej: SiG) oraz Słowa i Zdania (dalej SiZ). ${ }^{6} \mathrm{~W}$ ka-

5 Opisywane badania były częścia projektu realizowanego przez Poradnię Psychologiczno-Pedagogiczna numer $5 \mathrm{w}$ Warszawie. Badania prowadzone były w okresie od kwietnia do listopada 2015 roku w trzech żłobkach w dzielnicy Praga Północ w Warszawie. Łącznie przebadano 167 dzieci. Głównym celem projektu była ogólna, wstępna ocena stanu mowy dzieci w wieku od 24 do 36 miesięcy. Badania umożliwiły pozyskanie danych ilościowych na temat zaburzeń i opóźnień rozwoju mowy. Zgromadzony materiał językowy stał się podstawa przedstawionej w artykule analizy. Badania pokazały, że duża grupa - 18,35\% (29 dzieci) nie łączyła wyrazów w wypowiedzi dwuwyrazowe - nie tworzyła więc struktur syntaktyczno-semantycznych. $Z$ kolei mowa 25,9\% (41 dzieci) była niezrozumiała. Stąd też dokonanie dokładnej transkrypcji wypowiedzi było możliwe jedynie w wypadku 50 dzieci.

6 Sa to narzędzia diagnostyczne służące wstępnej ocenie poziomu rozwoju mowy dzieci w wieku odpowiednio: 8-18 miesięcy oraz 18-36 miesięcy. Kwestionariusze te sa polska adaptacja amerykańskich inwentarzy do badania rozwoju mowy dzieci MacArthur-Bates. Informacje o rozwoju dziecka pochodza $z$ obser- 
tegorii „czasowniki” kwestionariusza SiG znajdują się leksemy: biegać, chodzić, iść / pójść, jechać / jeździć, przyjść, skakać, uciekać. W drugiej części (SiZ): biec / biegać, chodzić (chodź), gonić, iść / pójść, jechać / jeździć, lecieć / latać, przyjść, uciekać. Warto zauważyć, że przy tworzeniu listy słów za podstawę selekcji materiału przyjęto dane leksykalne siedmiorga dzieci w wieku do 3 lat $z$ tzw. dzienników Szumanowskich. ${ }^{7} \mathrm{Na}$ podstawie tego materiału sporządzono robocze listy frekwencyjne słów używanych przez dzieci do lat trzech [Smoczyńska i in. 2015a, 22].

Wybór tej właśnie grupy czasowników znajduje uzasadnienie także w słowniku frekwencyjnym Słownictwo dzieci $w$ wieku przedszkolnym $w$ latach 2010-2015 [Zgółkowa 2016]. Szczególnie interesująca wydaje się lista rangowa. Na pierwszych 100 miejscach znajduje się 20 czasowników, w tym 4 czasowniki ruchu: iść, chodzić, pójść, jechać. W 1005 hasłach o frekwencji > 9 występuje 25 czasowników ruchu. Wyrazy $z$ frekwencja powyżej 9 zalicza się w statystyce leksykalnej do klasy słownictwa częstego. Klasę tę dzieli się niekiedy na podklasy: słownictwo bardzo częste ( $\mathrm{f} \geq 50)$, słownictwo częste $(20 \leq \mathrm{f}<50$ i $9<\mathrm{f}<20)$ [Święcicka 2017, 33]. W słowniku H. Zgółkowej [2016] słownictwo bardzo częste obejmuje 222 wyrazy. Wśród nich jest 7 czasowników ruchu (na 49 czasowników ogółem).

Podobne wnioski przedstawia Małgorzata Święcicka, która przeanalizowała słownik frekwencyjny Słownictwo dzieci w wieku przedszkolnym. Listy frekwencyjne z 1987 roku. W jednym $z$ artykułów stwierdza ona, że czasowniki bardzo częste mieszcza się wśród 226 wyrazów na liście rangowej. „Najliczniejsze sa czasowniki ruchu, podstawowe i pochodne od nich (iść, pójść, chodzić, przychodzić, przejść, wyjść, wejść), oraz czasowniki modalne" [Święcicka 2017, 38]. Halina Zgółkowa zauważa, że wśród czasowników, którymi posługują się dzieci, można wyróżnić trzy grupy tematyczne. Pierwsza, szczególnie bogata, zwiąana jest $z$ ruchem i poruszaniem się, co zdaniem autorki odzwierciedla rzeczywista „ruchliwość” dzieci [Zgółkowa 1990, 69]. Słownik minimum języka polskiego H. Zgółkowej zawiera 2144 hasła, w tym 451 czasowników. Wśród nich autorka

wacji rodziców, analizą zaś pozyskanych w ten sposób danych zajmują się specjaliści - psychologowie oraz logopedzi. Kwestionariusze zawierają listę kilkuset wyrazów pogrupowanych w kategorie znaczeniowe i gramatyczne.

$7 \mathrm{~W}$ polskich badaniach nad rozwojem mowy dzieci tworzeniem korpusów zajmowali się przede wszystkim badacze tzw. szkoły szumanowskiej - od nazwiska ich pomysłodawcy, psychologa Stefana Szumana. Wspomniane dzienniki to korpusy tekstów dziecięcych. Dane językowe były spisywane przez matki, psycholożki, obserwacje prowadzono w sposób usystematyzowany, w określonych odstępach czasu. W dziennikach tych novum stanowiło skrupulatne notowanie informacji o sytuacji komunikacyjnej, otoczeniu dziecka, reakcji rozmówców. Jednostka poddawana analizie miała być wypowiedź dziecka wraz z domniemanym znaczeniem. 
wydzieliła kategorię semantyczną „ruch ze zmianą miejsca”, w której znalazło się 49 czasowników.

Czasownikom ruchu w mowie dzieci poświęciła artykuł Anna Huk. Autorka $z$ nagrań swobodnych rozmów i zabaw aranżowanych wyekscerpowała materiał językowy zawierający struktury zdaniowe $z$ użyciem 11 czasowników ruchu, zróżnicowanych co do kierunku. ${ }^{8}$ Czasownikiem występującym najczęściej był czasownik iść. Ciekawym wnioskiem płynącym $z$ badań A. Huk było stwierdzenie, iż przy eksplikacji znaczeń danych czasowników dzieci najczęściej używają definicji syntaktycznej, prezentując pozycje otwierane przez orzeczenie.

\section{STRUKTURY ZDANIOWE KONSTYTUOWANE PRZEZ CZASOWNIKI RUCHU W MOWIE DZIECI}

Sposób realizacji struktur zdaniowych przez dzieci jest związany $z$ poziomem opanowania przez nie poszczególnych podsystemów języka. Dziecko w procesie gramatykalizacji ${ }^{9}$ stopniowo przechodzi od realizacji wypowiedzeń jednoelementowych (wypowiedzeń nierozczłonkowanych) do struktur coraz bardziej rozbudowanych pod względem semantyczno-składniowym, poczynając od dwuelementowych. Dalszy rozwój struktur syntaktycznych, wzbogacanie ich o kolejne składniki, postępuje stopniowo wraz z rozwojem podsystemu leksykalnego. Struktury trzy- i czteroelementowe utrzymuja się w mowie przez cały okres przedprzedszkolny oraz przedszkolny i sa uznawane za konstrukcje podstawowe w mowie dziecka [Przetacznikowa 1968, 426-435].

$\mathrm{W}$ zebranym materiale językowym wyodrębniłam 64 leksemy ${ }^{10}$ czasownikowe. Wśród nich znalazło się 18 czasowników oznaczających przemieszczanie się: iść, chodzić, wchodzić, wychodzić, przyjść, wspinać się, lecieć, pływać, płynać, jechać, jeździć, wjechać, zjeżdżać, wozić, przywieźć, huśtać się, bujać się, kręcić się. Poniżej przedstawiam je w postaci słowniczka, zawierającego charakterystykę wyodrębnionych jednostek

8 Autorka przeanalizowała czasowniki: chodzić, iść, jechać, jeździć, lecieć, latać, pływać, przychodzić, wychodzić, spaść, wrócić.

9 W literaturze logopedycznej przez gramatykalizacje rozumie się proces przyswajania przez dziecko reguł gramatycznych [por. Porayski-Pomsta 2011, 188]. Takie znaczenie terminu przyjmuję w artykule.

${ }_{10} \mathrm{~W}$ artykule posługuję się pojęciem leksem w odniesieniu do jednostek językowych wyodrębnionych w języku badanych dzieci. Zdaję sobie jednak sprawę, że badanie dziecięcych wypowiedzi pełne jest pułapek, choćby dlatego, że w początkach rozwoju języka część realizacji to reprodukcje zasłyszanych wypowiedzi innych jego użytkowników. Dzieci znają tylko niektóre formy fleksyjne, relacje paradygmatyczne i syntagmatyczne. Trudno jest orzec, w którym momencie dziecko staje się językowo twórcze - prawdopodobnie jest to kwestia indywidualna, zależna od osobniczej chronologii rozwoju. 
leksykalnych oraz wzorce konotacyjne przez nie wyznaczane i stworzone przeze mnie przykłady realizacji.

BUJAĆ SIĘ: ndk, orzeczenie motoryczne złożone (ruch wielokierunkowy wahadłowy, wielokrotny); ktoś - buja się - skądś - dokądś - którędy ${ }^{11}$ - za pomoca czegoś - w jakimśs celu. Hania bujała się na krześle.

CHODZIĆ: ndk, orzeczenie ruchu prostego (ruch wielokierunkowy niewahadłowy); ktoś - chodzi - skądś - dokądś - którędy - za pomoca czegoś - w jakimś celu. Jan zawsze chodził z ogrodu do domu przez łakkę. Jan chodził od sklepu do sklepu w poszukiwaniu idealnych butów.

HUŚTAĆ SIĘ: ndk, orzeczenie motoryczne złożone (ruch wielokierunkowy wahadłowy, wielokrotny); ktoś - huśta się - skądś - dokądś - którędy - za pomocą czegoś - w jakimś celu. Hania huśtała się na huśtawce. Wieczorami dla relaksu huśtałam się $w$ hamaku na balkonie.

IŚć: ndk, orzeczenie ruchu prostego (ruch jednokierunkowy); ktoś - idzie - skądś - dokądś - którędy - za pomocą czegoś - w jakimś celu. Jan szedł na rękach z pokoju do kuchni przez korytarz. Anna szła z domu do pracy przez park. Jan szedł tędy do sklepu po bułki.

JECHAĆ: ${ }^{12}$ ndk, orzeczenie motoryczne złożone (ruch jednokierunkowy); ktoś - jedzie - skądś - dokądś - którędy - za pomoca czegoś - w jakimś celu. Ania jedzie pociagiem $z$ Warszawy do Gdańska przez Bydgoszcz na koncert.

JEŹDZIĆ: ndk, orzeczenie motoryczne złożone (ruch wielokierunkowy niewahadłowy, wielokrotny); ktoś - jeździ - skądś - dokądś - którędy - za pomoca czegoś - w jakimś celu. Ania codziennie jeździ samochodem

11 W wypadku czasowników bujać się, huśtać się, kręcić się wystąią ograniczenia powierzchniowych realizacji pozycji lokatywnych, których znaczenie jest wbudowane w treść czasownika, a także ograniczenia dotyczące pozycji celu.

$12 \mathrm{~W}$ artykule przedstawiam jeden wzorzec konotacyjny czasownika jechać, najczęściej realizowany w analizowanym materiale. Warto zwrócić uwagę, że w przykładach: Dziewczynka jechała $z$ górki na rowerze i Rower jechał z górki moga być realizowane różne jednostki. W drugim przykładzie jechać blokuje pozycję dla środka transportu, bo pojawia się on w pozycji podmiotu (jako obiekt). Pojawia się jednak pytanie, czy problem nie leży po stronie właściwości agensa, nie zaś samego predykatu. Jest możliwa także inna interpretacja tego zdania - jednostka jest ta sama, jednak jej treść jest skondensowana - żaden środek transportu nie jedzie sam - samochód potrzebuje kierowcy, samolot pilota, statek sternika. Dodatkowo środki transportu sa przeznaczone do zmiany miejsca położenia osób lub rzeczy, zawsze więc to ktoś lub coś porusza się za ich pomoca. Podobne wątpliwości moga dotyczyć czasowników: jeździć, wjechać, zjeżdżać, a także lecieć, płynąć, pływać, choć w wypadku tych ostatnich należałoby rozważyć jeszcze jedno kryterium rozróżniania jednostek, związane $z$ uznaniem ruchu za autonomiczny lub nie: por. Marek pływa w jeziorze. Łódka płynie po jeziorze. Bociany leca nad łakka. Samolot leci nad miastem. Zdaję sobie sprawę, że rozstrzygnięcia te moga wynikać raczej $z$ wiedzy o świecie niż $z$ samego języka i przyjęte w artykule ustalenia wymagaja dalszej weryfikacji. 
autostrada $z$ Warszawy do Gdańska przez Bydgoszcz do pracy. Pociag z Warszawy do Olsztyna jeździ przez Działdowo.

KRĘCIĆ SIĘ: ndk, orzeczenie motoryczne złożone (ruch wielokierunkowy niewahadłowy, wielokrotny); ktoś - kręci się - skądś - dokądś - którędy - za pomocą czegoś - w jakimś celu. Hania kręciła się na karuzeli.

LECIEC $\dot{C}_{1}$ : ndk, orzeczenie ruchu prostego (ruch jednokierunkowy); ktoś - leci - skądś - dokądś - którędy - za pomocą czegoś - w jakimś celu. Bociany leciały na południe.

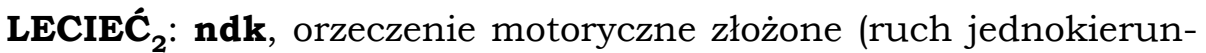
kowy); ktoś - leci - skądś - dokądś - którędy - za pomoca czegoś - w jakimś celu. Samolot leciał $z$ Warszawy do Londynu. Ania leciała samolotem $z$ Warszawy do Singapuru na wycieczkę.

PLYNĄ்́: ndk, orzeczenie ruchu prostego (ruch jednokierunkowy); ktoś - płynie - skądś - dokądś - którędy - za pomocą czegoś - w jakimś celu. Łososie płyna pod prad od ujścia do źródła rzeki, by złożyć ikrę.

PLYWAĆ: ndk, orzeczenie ruchu prostego (ruch wielokierunkowy niewahadłowy); ktoś - pływa - skądś - dokądś - którędy - za pomoca czegoś - w jakimś celu. Hania pływała od żółtej do czerwonej boi wzdłuż basenu. Hania plywała w jeziorze codziennie.

PRZYJŚĆ: dk, orzeczenie ruchu prostego (ruch jednokierunkowy); ktoś - przyszedl - skądś - dokądś - którędy - za pomocą czegoś - w jakimś celu. Hania przyszła do domu z przedszkola przez park. Wiesz, że nowa trasa udało mi sie przyjść ze szkoły do domu w 25 minut?

PRZYWIEŹĆ: dk, orzeczenie motoryczne złożone (ruch jednokierunkowy), kauzatywne; ktoś - przywiózl - kogoś / coś - skądś - dokądś - którędy - za pomocą czegoś - w jakimś celu. Tata przywiózł Hanię do przedszkola samochodem. Ponieważ Świętokrzyska była zamknięta, Jan przywiózł mamę taksówka $z$ dworca do domu Alejami.

WCHODZIĆ: ndk, orzeczenie ruchu prostego (ruch jednokierunkowy); ktoś - wchodzi - skądś - dokądś - którędy - za pomocą czegoś - w jakimś celu. $Z$ pierwszego piętra na drugie Hania zawsze wchodziła schodami przeciwpożarowymi. Jan wchodzil na zjeżdżalnię po drabince.

WJECHAĆ: dk, orzeczenie motoryczne złożone (ruch jednokierunkowy); ktoś - wjechal - skądś - dokądś - którędy - za pomocą czegoś - w jakimś celu. Marek wjechat do Olsztyna od strony Kortowa. Dziewczynka wjechała rowerem $w$ kałuże dla zabawy.

WOZIĆ: ndk, orzeczenie motoryczne złożone (ruch wielokierunkowy niewahadłowy, wielokrotny), kauzatywne; ktoś - wozi - kogoś / coś - skądś - dokądś - którędy - za pomocą czegoś - w jakimś celu. Jan codziennie wozi Anie samochodem z Warszawy do Gdańska do pracy. 
Wieczorami mama woziła Hanię przez kładkę na rzece, by w końcu zasnęła.

WSPINAĆ SIE: : ndk, orzeczenie motoryczne złożone (ruch jednokierunkowy); ktoś - wspina się - skądś - dokądś - którędy - za pomoca czegoś - w jakimś celu. Hania wspinała się po drabinkach. Turysta wspinat się na najwyższy szczyt Tatr czarnym szlakiem.

WYCHODZIĆ: ndk, orzeczenie ruchu prostego (ruch jednokierunkowy); ktoś - wychodzi - skądś - dokądś - którędy - za pomocą czegoś - w jakimś celu. Hania często wychodziła $z$ domu tylnym wyjściem. Ze strychu na dach wychodziło sie przez dobrze zamaskowane drzwi. Jan wychodził do pracy punktualnie.

ZJEŻḊ̇AĆ $\dot{\mathbf{1}}_{\mathbf{1}}$ : ndk, orzeczenie ruchu prostego (ruch jednokierunkowy); ktoś - zjeżdża - skądś - dokądś - którędy - za pomocą czegoś $\mathrm{w}$ jakimś celu. Hania zjeżdża na zjeżdżalni. ${ }^{13}$

ZJEŻDŻA $\dot{\mathbf{C}}_{\mathbf{2}}$ : ndk, orzeczenie motoryczne złożone (ruch jednokierunkowy); ktoś - zjeżdża - skądś - dokądś - którędy - za pomocą czegoś - w jakimś celu. Dzieci zjeżdżały na sankach z górki. Dziewczynka zjeżdżała na rowerze z góry przez las.

Realizacje dziecięce przedstawiam w tabeli 1 . W kolumnie pierwszej znajduja się informacje na temat poświadczonych w materiale form czasownikowych oraz ich frekwencji. Wersalikami zapisałam leksemy, w nawiasie podaję liczbę użyć. Druga kolumna to przykłady wypowiedzi dziecięcych. Formy nienormatywne (błędy fleksyjne, brak przedrostków, zaimków zwrotnych, przyimków) zostały zaznaczone pogrubieniem (pogrubione zostały tylko niepoprawne formy badanych czasowników ruchu) lub symbolem . Trzecia zawiera uwagi na temat użyć konkretnych czasowników.

13 Rozróżnienie między narzędziem a lokalizatorem perlatywnym, a co za tym idzie - klasyfikowanie danego predykatu jako orzeczenia ruchu prostego lub motorycznego złożonego, w wielu wypadkach było kłopotliwe. W artykule przyjmuję, że ruch złożony oznacza wspólne poruszanie się narzędzia i agensa względem jakiegoś punktu odniesienia. Za narzędzia uznaję więc m.in. rower, samolot, samochód, huśtawkę, karuzelę. Inaczej rozumiem sytuację, gdy ruch agensa odbywa się względem przedmiotu, np. drabiny, zjeżdżalni, schodów. W realizacji struktur zdaniowych uznaję je za lokalizatory perlatywne, określające tor przemieszczania się. Znów należałoby jednak zapytać, czy różnice te nie sa raczej zwiąane $z$ wiedzą o świecie niż $z$ właściwościami predykatów. 
Tabela 1. Realizacja zdań z czasownikami ruchu przez dzieci

\begin{tabular}{|c|c|c|}
\hline Czasownik & Przykładowe realizacje & Uwagi \\
\hline $\begin{array}{l}\text { BUJAĆ SIE (11) } \\
\text { buja się (9) } \\
\text { bujam sie (1) } \\
\text { buja (1) }\end{array}$ & $\begin{array}{l}\text { Lubie to, bujam się. } \\
\text { Buja się. } \\
\text { Buja buja, bujubuju, buja się. } \\
\text { A ja tu się bujam. } \\
\text { (A te dzieci?) Bujaja tutaj. } \\
\text { (A dziewczynka?) Buja . } \\
\text { Buja się na huśtawce. }\end{array}$ & $\begin{array}{l}\text { - na ogół przy czasowniku nie } \\
\text { jest realizowana żadna } \\
\text { z wymaganych pozycji; } \\
\text { - raz zrealizowana pozycja } \\
\text { agensa, raz pozycja narzędzia; } \\
\text { - w dwóch wypowiedziach brak } \\
\text { się; }\end{array}$ \\
\hline $\begin{array}{l}\text { CHODZIĆ (8) } \\
\text { chodzi (2) } \\
\text { chodził (2) } \\
\text { chodziłyśmy (1) } \\
\text { chodziłem (1) } \\
\text { chodzimy (1) } \\
\text { chodzę (1) }\end{array}$ & $\begin{array}{l}\text { Jak chodziłyśmy z babcia Ela } \\
\text { do mojego domku. } \\
\text { Ja też chodze na basen. } \\
\text { Chodziłem. } \\
\text { A wy chodzicie na plac zabaw? } \\
\text { Chodzimy. } \\
\text { Chodzi. } \\
\text { Chodzi. Chodzit. Idzie. }\end{array}$ & $\begin{array}{l}\text { - na ogół przy czasowniku nie } \\
\text { jest realizowana żadna } \\
\text { z pozycji lub jest realizowana } \\
\text { jedna pozycja - lokalizatora } \\
\text { adlatywnego; } \\
\text { - w jednej wypowiedzi } \\
\text { zrealizowana pozycja agensa } \\
\text { i co-agensa; }\end{array}$ \\
\hline $\begin{array}{l}\text { HUŚTAĆ SIE (9) } \\
\text { huśta sie (5) } \\
\text { huśtaja się (2) } \\
\text { huśtaja (1) } \\
\text { huśta (1) }\end{array}$ & $\begin{array}{l}\text { Huśta sie na huśtawce. } \\
\text { A ona się huśta. } \\
\text { Tu się huśtaja i skakaja. } \\
\text { Huśtaja. } \\
\text { Huśta. }\end{array}$ & $\begin{array}{l}\text { - na ogół przy czasowniku nie } \\
\text { jest realizowana żadna pozycja; } \\
\text { - raz zrealizowana pozycja } \\
\text { agensa i raz narzędzia; } \\
\text { - w dwóch wypowiedziach } \\
\text { pominięto się; }\end{array}$ \\
\hline $\begin{array}{l}\text { IŚĆ (14) } \\
\text { idzie (11) } \\
\text { poszedł (1) } \\
\text { poszedłem (2) }\end{array}$ & $\begin{array}{l}\text { Idzie misiem. } \\
\text { Idzie po drabinie. } \\
\text { Idzie po drabince. } \\
\text { Idzie domu. } \\
\text { Idzie na schodach, bo musi } \\
\text { zjeżdżać. } \\
\text { Idzie na tym, bo sobie chce } \\
\text { pojechać na tym. } \\
\text { Poszedł do nieba i nie wrócił. } \\
\text { Posztem tu i zoo poszedtem. } \\
\text { Idzie do basenu. } \\
\text { Idzie do szkoły. } \\
\text { Idzie na drabinkach. }\end{array}$ & $\begin{array}{l}\text { - na ogół przy czasowniku jest } \\
\text { realizowana jedna pozycja: } \\
\text { lokalizatora adlatywnego lub } \\
\text { perlatywnego; } \\
\text { - w jednej wypowiedzi } \\
\text { zrealizowana pozycja agensa } \\
\text { i co-agensa; } \\
\text { - pomijanie przyimków lub } \\
\text { niewłaściwy przyimek; }\end{array}$ \\
\hline
\end{tabular}




\begin{tabular}{|c|c|c|}
\hline Czasownik & Przykładowe realizacje & Uwagi \\
\hline $\begin{array}{l}\text { JECHAĆ (21) } \\
\text { jedzie }(17) \\
\text { jechała }(2) \\
\text { jecha }(2)\end{array}$ & $\begin{array}{l}\text { Jedzie na rowerku. } \\
\text { Jedzie na rowerze. } \\
\text { Jedzie na rowerze. (i co jej się } \\
\text { przytrafiło?) } \\
\text { Kuku. Bo jeździała na } \\
\text { rowerze. } \\
\text { Jeżdżała na rowerze powoli. } \\
\text { Dziewczynka jedzie na } \\
\text { rowerze. } \\
\text { Jecha na rowerze. } \\
\text { Jedzie na rowerze. } \\
\text { Jedzie rowerkiem. } \\
\text { Jedzie ower. } \\
\text { Jedzie. (A jak jedzie?) Po } \\
\text { trawie. } \\
\text { Przewróciła sie, bo szybko } \\
\text { jechała. } \\
\text { Jedzie na rowerze i spadła na } \\
\text { rowerze. } \\
\text { Jedzie (Na czym?) Na rowerze } \\
\text { (A jak?) O tak. Jak ja. } \\
\text { Ja jedziem } \text { alom. } \\
\text { Jedzie na rowerze. Bez misia. }\end{array}$ & $\begin{array}{l}\text { - na ogół przy czasowniku } \\
\text { jest realizowana jedna } \\
\text { pozycja, najczęściej narzędzia; } \\
\text { dwukrotnie zrealizowana } \\
\text { pozycja agensa; w jednej } \\
\text { wypowiedzi zrealizowana } \\
\text { pozycja co-agensa; } \\
\text { - dwukrotnie użyty przysłówek } \\
\text { - szybko, powoli } \\
\text { - niekonotowany; } \\
\text { - błędy fleksyjne: } \\
\text { jeżdżała brak przedrostka } \\
\text { z- (wtedy inny leksem - } \\
\text { ZJEŻDŻAĆ) lub jė̇ḋ̇ała } \\
\text { zamiast jechała; } \\
\text { jeździała zamiast jeździła lub } \\
\text { zjeżdżała; } \\
\text { jecha zamiast jedzie; } \\
\text { jedziem zamiast jade;; } \\
\text { - pomijanie przyimków lub } \\
\text { niewłaściwy przyimek; }\end{array}$ \\
\hline $\begin{array}{l}\text { JEŹDZIĆ (3) } \\
\text { jeździ (3) }\end{array}$ & $\begin{array}{l}\text { Jeździ jak ja na zjeżdżalni. } \\
\text { Ta jeździ na rowerze a misiu } \\
\text { łapie ja. } \\
\text { Jechała. } \\
\text { Jeździ na zjeżdżalni. }\end{array}$ & $\begin{array}{l}\text { - na ogół przy czasowniku jest } \\
\text { realizowana jedna pozycja; } \\
\text { dwukrotnie zrealizowana } \\
\text { pozycja lokalizatora } \\
\text { perlatywnego; w jednej } \\
\text { wypowiedzi zrealizowana } \\
\text { pozycja narzędzia; }\end{array}$ \\
\hline $\begin{array}{l}\text { KRECIĆ } \operatorname{SIE}_{\iota}(1) \\
k r e ̨ c i(1)\end{array}$ & $\begin{array}{l}\text { Tu jest karuzela i kręci } \\
\text { szybko. }\end{array}$ & $\begin{array}{l}\text { - przy czasowniku nie jest } \\
\text { zrealizowana żadna pozycja } \\
\text { konotowana; } \\
\text { - użyty przysłówek - szybko, } \\
\text { niekonotowany; } \\
\text { - brak segmentu się; }\end{array}$ \\
\hline $\begin{array}{l}\text { LECIEC }_{2}(2) \\
\text { leci }(2)\end{array}$ & $\begin{array}{l}\text { Samolot leci. } \\
\text { Molot leci. }\end{array}$ & $\begin{array}{l}\text { - na ogół przy czasowniku jest } \\
\text { realizowana jedna pozycja: } \\
\text { agensa, przy czym nie jest to } \\
\text { agens osobowy; }\end{array}$ \\
\hline $\begin{array}{l}\operatorname{LECIEĆ}_{1}(1) \\
\text { lecieli (1) }\end{array}$ & A już lecieli bociany. & $\begin{array}{l}\text { - przy czasowniku jest } \\
\text { zrealizowana (niepoprawnie) } \\
\text { jedna pozycja konotowana } \\
\text { - błąd fleksyjny: lecieli zamiast } \\
\text { leciaty; }\end{array}$ \\
\hline
\end{tabular}




\begin{tabular}{|c|c|c|}
\hline Czasownik & Przykładowe realizacje & Uwagi \\
\hline $\begin{array}{l}\text { PŁYNAĆ (3) } \\
\text { płynie } 3 \mathrm{x}\end{array}$ & $\begin{array}{l}\text { Płynie kołem. } \\
\text { Płynie. }\end{array}$ & $\begin{array}{l}\text { - przy czasowniku jest } \\
\text { realizowana (niepoprawnie) } \\
\text { jedna pozycja: narzędzia lub } \\
\text { nie jest zrealizowana żadna } \\
\text { pozycja konotowana; }\end{array}$ \\
\hline $\begin{array}{l}\text { PŁYWAĆ (9) } \\
\text { pływa }\end{array}$ & $\begin{array}{l}\text { Ptywa w basenie. } \\
\text { Ptywa. On ptywa w basenie. } \\
\text { Ptywa wodzie. } \\
\text { Picha basenie. }\end{array}$ & $\begin{array}{l}\text { - przy czasowniku jest } \\
\text { realizowana jedna pozycja } \\
\text { - najczésiciej lokalizatora - } \\
\text { okolicznik lokatywny [por. } \\
\text { Kudra 1993, 12-13]; } \\
\text { - pomijanie przyimków; } \\
\text { - picha-oboczność yw : ich; }\end{array}$ \\
\hline $\begin{array}{l}\text { PRZYJŚĆ (1) } \\
\text { przyszła (1) }\end{array}$ & $\begin{array}{l}\text { Czemu przyszła ta druga } \\
\text { ciocia? }\end{array}$ & $\begin{array}{l}\text { - przy czasowniku jest } \\
\text { zrealizowana jedna pozycja: } \\
\text { agensa; } \\
\text { - brak pozycji lokalizatorów, } \\
\text { narzędzia, celu; }\end{array}$ \\
\hline $\begin{array}{l}\text { PRZYWIEŹĆ (2) } \\
\text { przywioźli (2) }\end{array}$ & $\begin{array}{l}\text { Też przywioźli, dwie przywieźli } \\
\text { (książki). }\end{array}$ & $\begin{array}{l}\text { - przy czasowniku realizowana } \\
\text { pozycja obiektu; } \\
\text { - przywioźli-oboczność e :o; }\end{array}$ \\
\hline $\begin{array}{l}\text { WCHODZIĆ (2) } \\
\text { wchodzi (2) }\end{array}$ & $\begin{array}{l}\text { Chłopiec wchodzi. } \\
\text { Wchodzi na zjeżdżalni , żeby } \\
\text { sobie pozjeżḋ̇ać. }\end{array}$ & $\begin{array}{l}\text { - przy czasowniku jest } \\
\text { realizowana jedna pozycja lub } \\
\text { dwie; raz pozycja agensa, raz } \\
\text { lokalizatora perlatywnego } \\
\text { i celu; } \\
\text { - błędny przyimek - na zamiast } \\
\text { po; }\end{array}$ \\
\hline 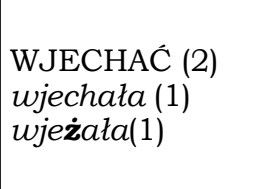 & $\begin{array}{l}\text { Bo wjė̇ała tutaj rowerkiem. } \\
\text { Wjechała tutaj rowerkiem. }\end{array}$ & $\begin{array}{l}\text { - przy czasowniku realizowane } \\
\text { są dwie pozycje: lokalizatora } \\
\text { adlatywnego i narzędzia; } \\
\text { - niepoprawna forma } \\
\text { wjeżała: }{ }^{14}\end{array}$ \\
\hline $\begin{array}{l}\text { WOZIĆ (1) } \\
\text { wozi (1) }\end{array}$ & A misiu ja trzyma i ja wozi. & $\begin{array}{l}\text { - przy czasowniku } \\
\text { zrealizowana jedna pozycja: } \\
\text { obiektu; }\end{array}$ \\
\hline $\begin{array}{l}\text { WSPINAĆ } \operatorname{SIE}_{c}(1) \\
\text { wspina się (1) }\end{array}$ & Wspina się. & $\begin{array}{l}\text { - przy czasowniku nie sa } \\
\text { realizowane żadne pozycje; }\end{array}$ \\
\hline
\end{tabular}

14 Zakwalifikowanie formy wjeżała do przykładów realizacji leksemu wjechać, nie zaś wjeżdżá, jest zwiazane $z$ kontekstem jej użycia. Cała wypowiedź wyglądała następująco: Bo wjeżała tutaj rowerkiem. Wjechała tutaj rowerkiem. Dziecko samo dokonało korekty formy wjeżała i zastapiło je prawidłowa forma wjechała. Rozważyć należałoby także kontaminację - w efekcie forma ta powinna się znaleźć w przykładach realizacji obu czasowników. 


\begin{tabular}{|c|c|c|}
\hline Czasownik & Przykładowe realizacje & Uwagi \\
\hline $\begin{array}{l}\text { WYCHODZIĆ (2) } \\
\text { wyszedł (1) } \\
\text { wyszła (1) }\end{array}$ & $\begin{array}{l}\text { Wyszedt budy. } \\
\boldsymbol{W} \text { domu wyszła. }\end{array}$ & $\begin{array}{l}\text { - przy czasowniku realizowana } \\
\text { jedna pozycja - lokalizatora; } \\
\text { - pomijanie przyimków lub } \\
\text { niewłaściwy przyimek; }\end{array}$ \\
\hline 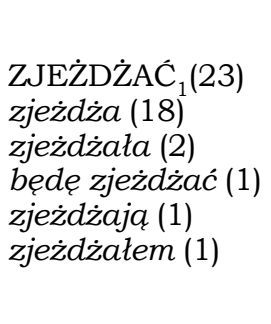 & 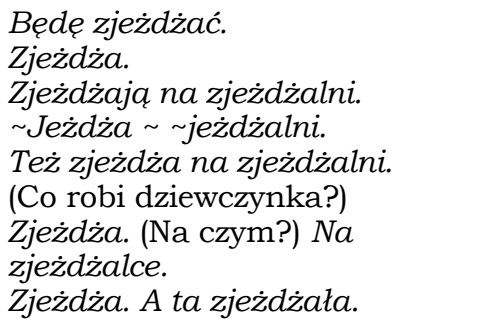 & $\begin{array}{l}\text { - na ogół przy czasowniku jest } \\
\text { realizowana jedna pozycja; } \\
\text { najczęściej jest to pozycja } \\
\text { lokalizatora; } \\
\text { - pomijanie przyimków lub } \\
\text { niewłaściwy przyimek; } \\
\text { - pomijanie przedrostka; }\end{array}$ \\
\hline $\begin{array}{l}\text { ZJEŻDŻAĆ }{ }_{2}(5) \\
\text { zjeżdżała (5) }\end{array}$ & $\begin{array}{l}\text { (i co jej się przytrafiło?) Kuku. } \\
\text { Bo jeżdżała na rowerze. } \\
\text { Zjeżdżała na rowerze i zrobiła } \\
\text { kuku. } \\
\text { A tutaj jest rower. Bo zjeżdżała } \\
\text { z górki. } \\
\text { Bo ona zjeżdżała w kamień. } \\
\text { Kuku sobie zrobiła. } \\
\text { Zjeżdżała z górki. }\end{array}$ & $\begin{array}{l}\text { - na ogół przy czasowniku jest } \\
\text { realizowana jedna pozycja; } \\
\text { najczęściej jest to pozycja } \\
\text { lokalizatora lub narzędzia; raz } \\
\text { zrealizowana pozycja agensa; } \\
\text { - pomijanie przedrostka; }\end{array}$ \\
\hline
\end{tabular}

\section{WNIOSKI}

Wnioski płynace $z$ analizy materiału potwierdzają obserwację, iż czasowniki ruchu sa grupa dobrze opanowana przez dzieci w wieku 2-3 lata. ${ }^{15}$ Czasowniki te nazywają czynności konkretne, bliskie dzieciom, częste, towarzyszace także zabawie. Duża frekwencja ich użycia przez dorosłych sprawia, że niektóre $z$ nich (iść, jechać) sa jednymi $z$ pierwszych czasowników, które pojawiają się w mowie dzieci. ${ }^{16}$ Co prawda niektóre $z$ nich (kręcić się, wozić, przyjść) pojawiły się jednokrotnie, nie mogły więc stać się podstawą dokładniejszej analizy, jednak ma to prawdopodobnie zwiazek $z$ wielkościa badanej grupy (50 dzieci) oraz prezentowanym podczas badania materiałem obrazkowym.

Wstępna analiza realizacji struktur zdaniowych prostych $z$ czasownikami ruchu pokazuje, że opanowanie podsystemu składniowego przez

15 Podobne wnioski, w odniesieniu do starszej grupy dzieci - dzieci w wieku przedszkolnym płyna $z$ analiz materiału językowego przeprowadzonych przez A. Huk [Huk 2008, 54-56].

16 Początkowo jako orzeczenia onomatopeiczne: brum-brum, zium [Smoczyńska i in. 2015, 9, 122]. 
dzieci nadal wymaga dokładniejszego zbadania, a co za tym idzie - może stać się problemem badawczym kolejnych opracowań.

\section{Bibliografia}

J. Apresjan, 2000, Semantyka leksykalna. Synonimiczne środki języka, Wrocław.

B. Bojar, 1977, Polskie czasowniki ruchu, „Polonica” t. 3, s. 97-139.

B. Bojar, 1979, Opis semantyczny czasowników ruchu oraz pojęć zwiazanych z ruchem, Warszawa.

M. Grochowski, 1973, Eksplikacje znaczeń czasowników ruchu [w:] M.R. Mayenowa (red.), Semiotyka i struktura tekstu. Studia poświęcone VII Międzynarodowemu Kongresowi Slawistów: Warszawa 1973, WrocławWarszawa-Kraków-Gdańsk, s. 189-200.

M. Grochowski, 1974, Klasyfikacja semantyczna jednomiejscowych czasowników ruchu współczesnego języka polskiego, „Prace Filologiczne” t. 24, s. 99-116.

A. Huk, 2008, Jakich czasowników ruchu używaja dzieci w wieku przedszkolnym? Semantyka i struktura gramatyczna czasowników ruchu, „Poradnik Językowy" z. 1, s. 52-61.

S. Karolak, 2002, Podstawowe struktury składniowe jezyka polskiego, Warszawa.

A. Kiklewicz, M. Korytkowska, 2010, Podstawowe struktury zdaniowe współczesnych języków słowiańskich: białoruski, bułgarski, polski, Olsztyn.

Z. Kubiszyn-Mędrala, 2006-2007, Polskie bezprzedrostkowe czasowniki ruchu w perspektywie semantyki kognitywnej [w:] Polsko-francuski projekt badawczy CASK (Polonium2006-2007), http:// celta.paris-sorbonne.fr/anasem/papers/Motion/CzasRuch.pdf [dostęp: 9.02.2019].

B. Kudra, 1993, Wpływ przedrostków na łączliwość składniowa czasowników ruchu, Łódź.

J. Porayski-Pomsta, 2011, Zagadnienie periodyzacji rozwoju mowy dziecka [w:] „Studia Pedagogiczne. Problemy Społeczne, Edukacyjne i Artystyczne” t. 20, s. $173-198$.

M. Przetacznikowa, 1968, Rozwój struktury i funkcji zdań w mowie dziecka [w:] S. Szuman (red.), O rozwoju języka i myślenia dziecka, Kraków, s. 383-652.

K. Sindrewicz, 2018, Logopedyczne badania przesiewowe dzieci $w$ wieku od 24 do 36 miesięcy [w]: D. Saniewska (red.), Białostockie Spotkania Młodych Logopedów. Varia, Białystok, s. 131-144.

M. Smoczyńska i in., 2015, Inwentarze Rozwoju Mowy i Komunikacji (IRMIK): Slowa i Gesty, Slowa i Zdania. Podręcznik, Warszawa.

M. Święcicka, 2017, Wyrazy częste $w$ „Stownictwie dzieci $w$ wieku przedszkolnym" [w:] M. Święcicka, Młoda mowa. Studia nad polszczyzna dzieci i młodzieży, s. 31-53.

P. Witkowska, 2017, Czasowniki zmiany pozycji ciała. Analiza formalna w ujęciu korpusowym $i$ statystycznym, Wrocław.

Z. Zaron, 2012, Wybrane problemy składni funkcjonalnej, Warszawa.

H. Zgółkowa, 1990, Świat w dziecięcych słowach, Poznań.

H. Zgółkowa, 2013, Słownik minimum języka polskiego, Kraków. 
H. Zgółkowa, 2016, Słownictwo dzieci $w$ wieku przedszkolnym $w$ latach 2010-2015, Poznań.

M. Żak-Święcicka, 1993, Charakterystyka składniowa wypowiedzi dzieci w wieku przedszkolnym, Bydgoszcz.

\title{
Sentence structures with verbs of movement in the speech of two- and three-year-old children
}

\begin{abstract}
Summary
The aim of this paper is to point to the issue of acquisition of the syntactic and inflectional subsystems in speech development, and in particular to development of simple sentence structures. Based on the language material covering fragments of utterances made by 50 children, collected during a screening conducted in 3 nurseries in Praga-Północ in 2015, I made a brief analysis of the utterances constituted by verbs of movement, a class characterised by high frequency and free use by the children. The findings confirm the thesis that verbs of movement are a group with which children aged 2-3 are well familiar.
\end{abstract}

Trans. Monika Czarnecka 